\title{
Subdural arachnoidal cyst of the spinal cord: etiology, clinical presentation, surgical strategy and results
}

\author{
Joelton Fonseca', José Carlos Lynch², Fabiana Policarpo', \\ Celestino Esteves ${ }^{3}$, Cleber Bomfim ${ }^{1}$, Leonardo Welling ${ }^{1}$ \\ Neurosurgical Department of Hospital Federal dos Servidores do Estado, Rio de Janeiro, RJ, Brasil.
}

\begin{abstract}
Objective: Of this study is identifying the clinical manifestations, discuss the etiology, and present the surgical treatment nuances and outcomes of patients with sub dural arachnoidal cysts (AC). Method: A retrospective study was carried out with 7 consecutives patients with spinal cord subdural $A C$, diagnosed, evaluated and operated at the Neurosurgical department of Servidores do Estado Hospital, from 1996 to 2010. The radiological studies, patient records, surgical descriptions and surgical videos, were reviewed, creating a database from which information was collected. The follow-up varied from 2 to 168 months (mean, 48 months). All cysts were histopathological verified. Results: Five AC were located on the thoracic spinal cord, one were located anterior in the cervical region, and one at the lumbar spinal level. The complete resection of the cyst was performed in 4 surgeries. Three patients had cysts located ventral to the cord, which precluded complete excision. The symptoms in four patients demonstrated major improvement. There was no operative death in this series, there was no major complications related to surgery. Conclusion: AC should be considered in the differential diagnosis of lesions causing myelopathy and/or a radicular pain syndrome. Microsurgical resection or generous fenestration in cysts effectively ameliorated patients' symptomatology.
\end{abstract}

\section{KEYWORD}

Arachnoid cysts, spinal cord compression, sciatica, myelitis, microsurgery.

\section{RESUMO}

Cisto aracnóideo subdural medular: etiologia, apresentação clínica, estratégia cirúrgica e resultados

Objetivo: Identificar as manifestações clínicas, discutir a etiologia, apresentar as opções terapêuticas e revelar os resultados de uma série de pacientes diagnosticados com cisto aracnoide medular subdural (CA). Método: Realizamos um estudo retrospectivo em que analisamos 7 pacientes com AC que foram operados no Hospital dos Servidores do Estado, entre 1996 e 2010. Os estudos de imagem, prontuários, descrições cirúrgicas e os vídeos foram analisados e os dados, coletados. O seguimento variou de 8 a 168 meses. Em todos os cistos foi realizado estudo histopatológico. Resultados: Cinco cistos se localizavam na medula torácica, um na cervical anterior e outro no segmento lombar. Obtivemos a excisão completa dos cistos em 4 pacientes, que apresentaram importante melhora dos sintomas. Não ocorreu nenhum óbito nessa série, nem piora do sintomas pré-operatórios. Conclusão: O CA deve ser considerado no diagnóstico diferencial das lesões que causam mielopatia ou síndrome radicular. A ressecção microcirúrgica ou uma ampla fenestração das paredes do cisto geralmente revertem os sintomas do pacientes.

\section{PALAVRAS-CHAVE}

Cistos aracnóideos, compressão da medula espinal, ciática, mielite, microcirurgia.

1 Resident of the Neurosurgical Department of Hospital Federal dos Servidores do Estado, Rio de Janeiro, RJ, Brazil.

2 Head of the Neurosurgical Department of Hospital Federal dos Servidores do Estado, Rio de Janeiro, RJ, Brazil.

3 Assistant of the Neurosurgical Department of Hospital Federal dos Servidores do Estado, Rio de Janeiro, RJ, Brazil. 


\section{Introduction}

Several different histological types of cysts located within or around the vertebral canal have been reported in the literature: aneurysmal bone cyst, ${ }^{1}$ cyst ligament, ${ }^{2}$ synovial cyst, ${ }^{3,4}$ cysticercosis, ${ }^{5}$ neurenteric cyst ${ }^{6}$ ependimal cyst, ${ }^{7,8}$ arachnoiditis, ${ }^{8}$ and arachnoid cyst (AC).

The subdural AC compressing the spinal cord is unusual lesions. They frequently arise posterior to the spinal cord, most of them are located in the thoracic spine. ${ }^{9-20}$ The majority of patients with a symptomatic intradural spinal AC have signs and symptoms of a myelopathic syndrome. AC should be considered in the differential diagnosis of lesions causing myelopathy and/or a radicular pain syndrome. Because for the aforementions reasons we decided reviewed our experience with this unusual lesion and present a clinical series, with 7 patients with spinal cord subdural AC, to identify the importance of the clinical manifestations, discuss the etiology, and present the surgical treatment nuances and outcomes.

\section{Method}

\section{Patient population}

A retrospective study was carried out with 7 consecutives patients with spinal cord subdural AC diagnosed, evaluated and operated at the Neurosurgical department of HSE, from 1996 to 2010. The Radiological studies, patient records, surgical descriptions, and when available, surgical videos, were reviewed, creating a database from which information pertinent to the present study was collected. The follow-up included clinic visits and/ or telephone calls for patients from outside of Rio de Janeiro. The follow-up varied from 3 to 168 months (mean, 48 months). All cysts were histopathological verified.

\section{Surgical procedure}

In all cases, the same microsurgery technique was used. After general endotracheal intubation, the patient was placed in the prone position. A midline incision is made to expose longitudinally from the cranial to the caudal end of the cyst. The paravertebral muscles were elevated subperiosteally and laterally retracted, exposing the spinous processes and lamina of the corresponding vertebras. Removal of the laminas is performed. In one adolescent patient, to preserve the stability of the spine, we performed a laminotomy. In this situation, the lamina and spinous processes were removed as a single unit by lifting the spinous processes with an instrument and separating all ligamentous connections with small Kerrison rongeur. The laminae were replaced with multiple mini plates and screws. The surgical microscope is introduced, and using a 10 to $16 \mathrm{x}$ magnification the duramater is sectioned in midline, allowing access to intradural compartment. The free border of the duramater is sutured in the paravertebral musculature. The cyst should be exposing it longitudinally from cranial to the caudal end. In 5 instances we found the AC located posterior or posterolateral to spinal cord, to be multilobulated by membranous trabeculae that bridged the most outer Arachnoid membrane and the vessels on the surface of the spinal cord. The cyst wall is fenestrated, the cerebrospinal fluid-like accumulated within the cyst, is gently aspirated and the cyst walls carefully ressected as much as possible, but without injury the neural elements.

Following, we make a microlysis of the adhesions that involves the spinal cord and roots. The closure of the paravertebral musculature and fascia is performed in 3 layers; the skin is sutured with 3.0 nylon.

\section{Illustrative case}

An 8-year-old girl developed a progressive walking difficulties. The neurological examination revealed a paraparesis; increase deep tendon reflexes and bilateral Babinski. Chest XR showed a thoracic scoliosis. MRI revealed a cystic lesion with signal characteristics similar to CSF at T2-T10 compressing anteriorly the spinal cord, for which she underwent laminotomy with extensive removal of the thin-walled cyst wall. The medulla was depressed but started immediately with a good pulsation. She made an uneventful recovery after surgery and retour to her normal life (Figures 1A, B, C, D e E).

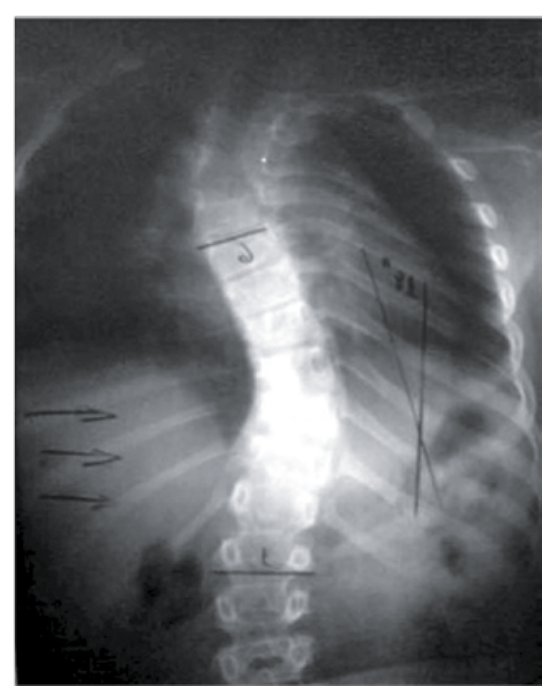

Figure $1 A$ - Chest $X$-ray detecting a thoracic scoliosis. 


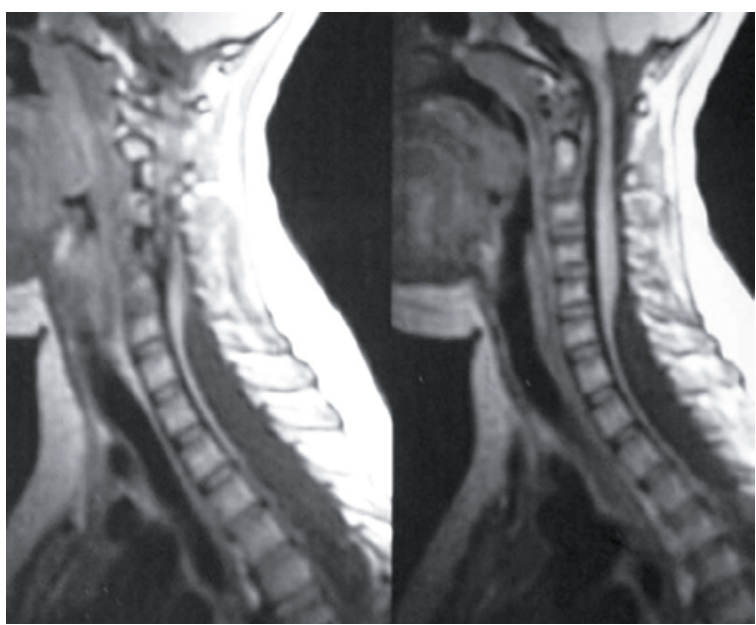

Figure 1B - Cervical MRI showing a large posterior cervicothoracic cyst lesion, located posterior to the spinal cord. Note the ventral displacement and deformation of the spinal cord.

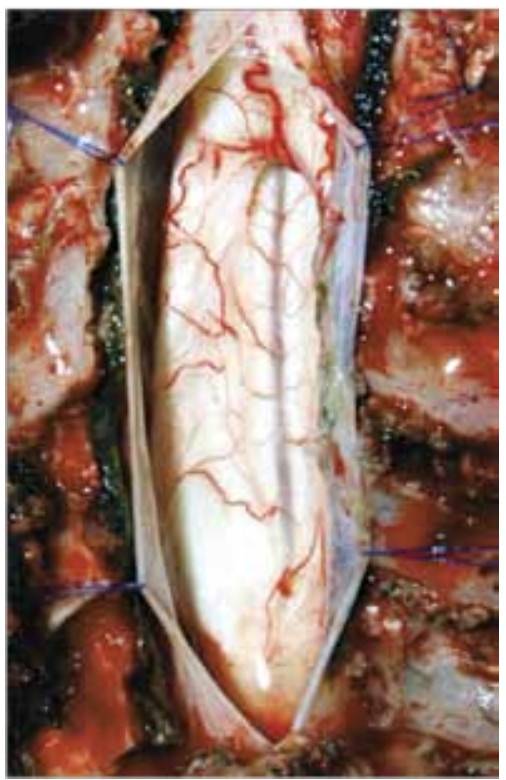

Figure 1C-Operative photograph showing the thin cystic arachnoid layer and the depressed spinal cord.

\section{Results}

In this series, there were 3 men and 4 women ranging in age from 8 to 44 years, average of 30.2 years. The duration of the symptoms varied from 1 to 36 months years (Table 1). In these, series all patients have signs and symptoms of a myelopathic syndrome and in 4, added radicular pain (Table 1).

The signs and symptoms are listed in the table 1. Four AC were located on the thoracic spinal cord, 1 were located anterior in the cervical region, and 1 at the posterior lumbar spinal level. Craniocaudal extension of dorsal Arachnoid cysts varied from 2 to 8 vertebral

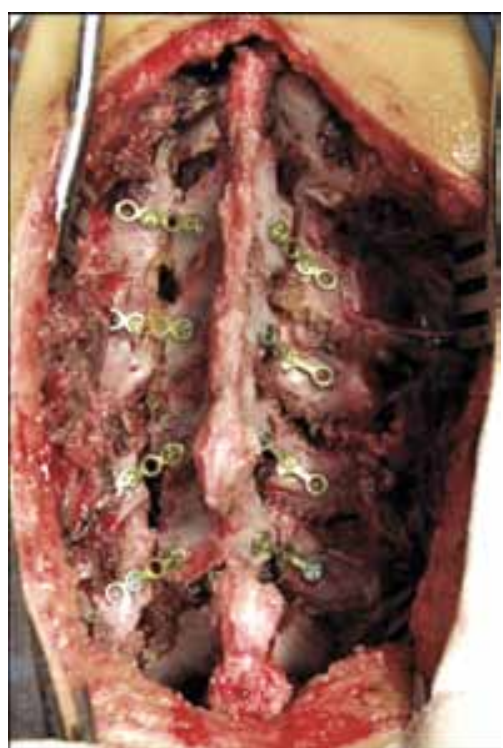

Figure 1D - Operative image of the fusion of laminothomy with mini plates.

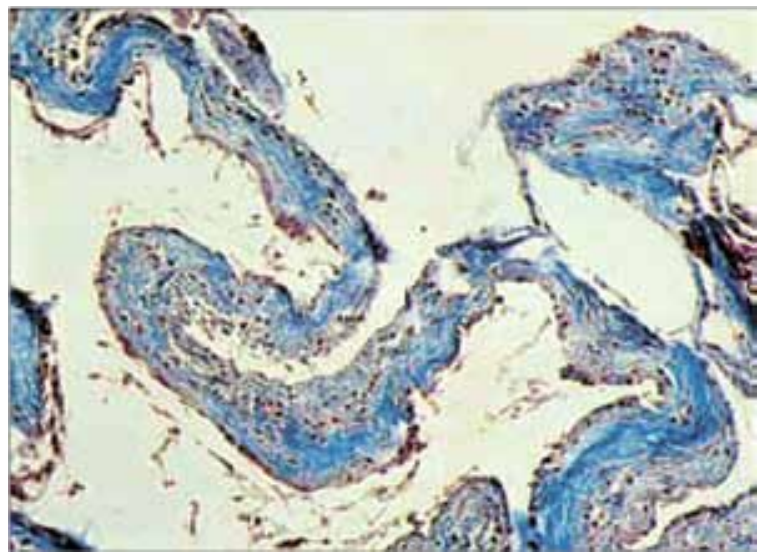

Figure $1 E-H y s t o l o g y$ of the cyst lesion wall revealing collagenous fibers membranes and an inner layer cuboid cells. $(\mathrm{H} / \mathrm{E}-50 \mathrm{X})$

levels (mean, 4.4 vertebral levels). Complete resection of the cyst was performed in 4 surgeries, all of whom had cysts situated dorsal or dorsolateral to the cord. Three patients had cysts located ventral to the cord, which precluded complete excision; therefore, they were wide open and marsupialized to the subarachnoid space. Histopathological examination revealed Arachnoid cysts, in all cases (Figure 1E). Symptoms in 4 patients demonstrated major improvement; there was no cyst recurrence on MRI after a mean follow-up period of 3.2 years. The follow-up varied from 0.3 to 12 years with an average of 5.7 years. There is no operative death in this series, there were no major complications related 
to surgery. None of these patients deteriorated after surgery. Two of the 7 patients with preoperative pain had significant improvement after surgery. During the follow up, we observed that 4 patients had an excellent or good early postoperative result, 2 had a fair result, and no improvement was noticed in one patient with long-standing myelopathy, with evidence during surgery, of adhesive arachnoiditis and atrophy of the spinal cord (Figures $2 \mathrm{~A}$ and $\mathrm{B}$ ). One of these 8 patients was lost in the follow-up.

\begin{tabular}{|c|c|c|c|c|c|c|c|c|}
\hline Patients & $\operatorname{Age}(\mathrm{Yr}) / \operatorname{Sex}$ & Trauma & $\begin{array}{c}\text { Clinical } \\
\text { presentations }\end{array}$ & Level & $\begin{array}{c}\text { Evolution time } \\
\text { (months) }\end{array}$ & Surgery & Site & Follow-up \\
\hline 1 & $16 / \mathrm{M}$ & Yes & Paraparesis & T10-T11 & 24 & $\begin{array}{l}\text { Laminectomy/ } \\
\text { Cyst removal }\end{array}$ & Posterior & Normal \\
\hline 2 & $44 / \mathrm{M}$ & No & Paraparesis & T8-T9-T10 & 2 & $\begin{array}{l}\text { Laminectomy/ } \\
\text { Cyst removal }\end{array}$ & Posterolateral & Normal \\
\hline 3 & $37 / \mathrm{F}$ & No & Pain/Paraparesis & T11-S1 & 36 & $\begin{array}{l}\text { Laminectomy/ } \\
\text { Fenestration }\end{array}$ & Posterolateral & No change \\
\hline 4 & $47 / \mathrm{F}$ & Yes & $\begin{array}{c}\text { Pain/ } \\
\text { Paraparesis }\end{array}$ & T9-T10 & 7 & $\begin{array}{l}\text { Laminectomy/ } \\
\text { Fenestration }\end{array}$ & Posterolateral & No change \\
\hline 5 & $\mathrm{O} 8 / \mathrm{F}$ & No & Pain/Paraparesis & $\mathrm{T} 2$ a $\mathrm{T} 10$ & 12 & $\begin{array}{l}\text { Laminotomy/ } \\
\text { Cyst removal }\end{array}$ & Posterior & Normal \\
\hline 6 & $18 / \mathrm{M}$ & Yes & Paraplegya & $\mathrm{C} 2-\mathrm{C} 3$ & 1 & $\begin{array}{l}\text { Laminectomy/ } \\
\text { Fenestration }\end{array}$ & Anterial & No change \\
\hline 7 & $42 / \mathrm{F}$ & No & Paraparesis & T5-T12 & 13 & $\begin{array}{l}\text { Laminectomy/ } \\
\text { Cyst removal }\end{array}$ & Posterolateral & Normal \\
\hline
\end{tabular}

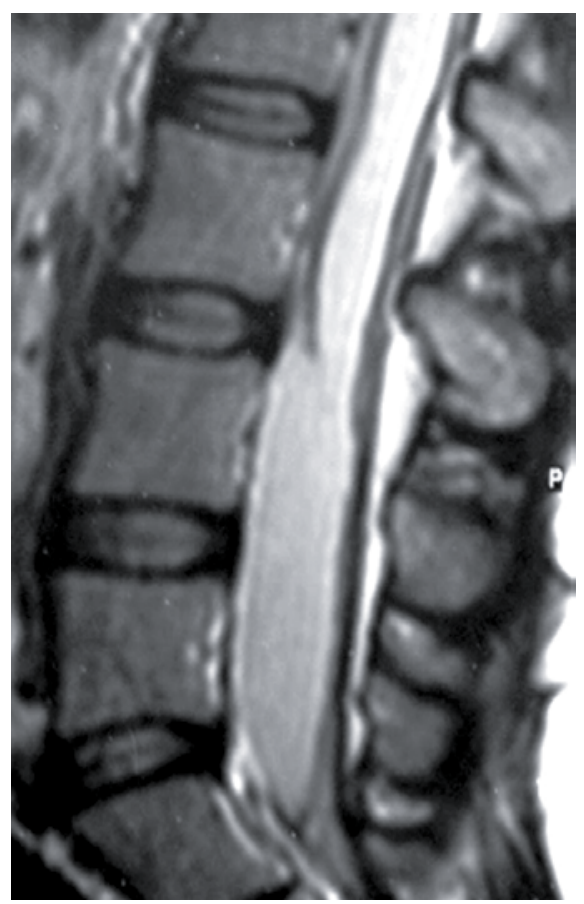

Figure 2A - Sagital T2 RMI detecting an anterior lumbar cyst.

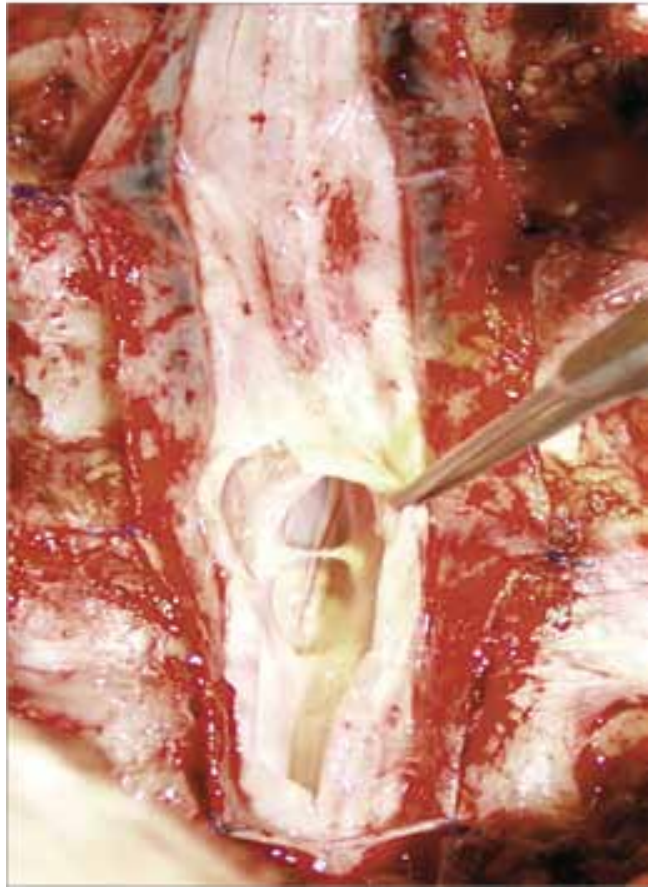

Figure 2B - Operative photographs showing a subdural cyst, hypertrophic meninge, aracnoditis and proliferative exsudate. 


\section{Discussion}

There are some limitations to this study. First, it is subject to all the biases of retrospective studies. Second, because no effort was made to randomize patients to various management paradigms, it simply presents our experience with these lesions, especially on the importance of performing whenever possible a total excision of AC, or a wide fenestration to ensure a near to physiological cerebrospinal fluid circulation and reduce the risk of recurrence.

\section{Pathogenesis}

Spinal AC has been termed by various authors as "arachnoid diverticula", "leptomeningeal cysts", "localized adhesive arachnoiditis", and "serous spinal meningitis" subarachnoid cysts, and meningeal hydrops ${ }^{13,15-17,21}$ according to different pathogenetic conceptions. The origin of spinal intradural AC is not always clear. Several hypotheses have been proposed to explain the formation of intradural AC, some lesions develop because of infection (case 4), trauma (case 3 and 6), surgery, subarachnoid hemorrhage, lumbar puncture, or neural tube defects; however, the majority of cysts are thought to be congenital or idiopathic, cases $(1,2,5,7$ and 8). 12,13,16,17,21-24 Some authors have observed intramedullary cavitations or a syrinx concomitant with an intradural arachnoid cyst. Osenbach et $a .^{21}$ observed a single case Klippel-Feil anomaly and cervical diastematomyelia among 11 patients harboring an intradural arachnoid cyst. Associated vertebral anomalies, most commonly kyphoscoliosis, were described in $71 \%$ of the patients in the series of Alvisi et al. ${ }^{25}$. Our case number 5 presents a thoracic kiphoscoliosis (Figure 1A). Table 1 showed the signs, symptoms; type of surgery and out come of 7 patients treated by our group.

The primary cyst seems to arise during development and, although present at birth, may expand and progressively compress the spinal cord and/or the roots. The majority of AC is located in the posterior aspect of thoracic spine. ${ }^{21}$ Perret et al. ${ }^{20}$ suggested that the AC arise from "diverticula" of the arachnoidal membranes, particularly from the relatively well-developed arachnoidal septum between the posterior dura and dorsal spinal cord (septum posticum). Although Perret's theory adequately explains dorsal cysts, it fails to account for those in a ventral location. Teng and Rudner ${ }^{26}$ proposed that normal daily variations of intraspinal CSF pressure lead to cyst formation through dilatation of low resistance areas within the Arachnoid. The pathological distribution of the Arachnoid trabeculae at areas with lower resistance, leads to a diverticulum. The trabecular cells degenerate, and increased pressure builds up within the cyst. ${ }^{16,17,23}$ Fortuna et al. ${ }^{22}$ have proposed that all types of Arachnoid diverticula result from hypertrophy, proliferation, and dilatation of arachnoid granulations. They theorized that if the dilatation were confined by a resistant dura, a subdural cyst would result, whereas a weakened or deficient dura would allow herniation of the Arachnoid along the path of least resistance into the epidural space to form an extradural cyst.

\section{Neuroimaging studies}

The primary MRI finding suggestive of this lesion is a subdural extramedullary space-occupying lesion. The cysts demonstrated signal characteristics similar to CSF, being of low intensity on T1-weighted images and progressing to high intensity with T2-weighting (Figures $1 \mathrm{~B}$ and 2A). All cysts, but two, were sufficiently delineated by MRI, including their location in relation to the spinal cord and their craniocaudal extension. Myelography is no longer routinely performed at our institution for preoperative diagnostic workup but the two first patients of this series were diagnosed by this method. Accord to Shimizu et al. ${ }^{27}$ the Cardiac cine magnetic study can provide valuable information for the evaluation of spinal subdural AC. First, the visualization of abnormal flow provides a more robust evidence of the presence of a cystic formation and may indicate the location of the cystic wall or septum to be opened surgically. Second, dynamic spinal cord compression by the cyst can also be shown. Unfortunately, this technology was not avaible for use in this series.

\section{Patient management}

Several authors believed that the primary indications for surgical intervention are pain that do not respond to conservative therapy and/or neurological deficit. $^{13,17,21-23,28,29}$

The majority published series showed the benefits of total excision of AC, however, in the cases that this is not feasible because fibrous adhesion of the wall of the cyst to neural structures or the anterior location in relation to spinal cord, a partial resection or fenestration should be performed as widely as possible ${ }^{13,17,21-23,29}$ (Table 2). From a technical point of view, not only one, but several stomas should be performed between the cyst and the subarachnoid space, as in order to reduce the risk of late closure and recurrence and obtain a free communication from the cyst to the normal subarachnoid space.

The treatment of a total or partial resection of cyst wall or fenestration produced an excellent return of neurological function in 4 of ours 7 patients. 


\begin{tabular}{|c|c|c|c|c|c|c|c|}
\hline $\begin{array}{l}\text { Series } \\
\text { Ref. } n^{\circ}\end{array}$ & $\begin{array}{c}\mathbf{N}^{0} \text { of } \\
\text { patients }\end{array}$ & Age (mean) & Origin & $\begin{array}{c}\text { Extension } \\
\text { (levels) }\end{array}$ & Surgical technique & $\begin{array}{c}\text { Results } \\
(\%)\end{array}$ & $\begin{array}{c}\text { F/U } \\
(\mathbf{Y R})\end{array}$ \\
\hline Palmer JJ (18), 1974 & 5 & 19.3 & Idiopathic $=4$ & 3.4 & $\begin{array}{c}\text { Ressection }=1 \\
\text { Fenestration }=4\end{array}$ & $\begin{array}{c}\text { Improve } \\
80 \%\end{array}$ & 5.5 \\
\hline Osenbach RK et al. (21), 1992 & 11 & 41 & Idiopathic $=9$ & 3.4 & $\begin{array}{c}\text { Ressection }=8 \\
\text { Fenestration }=3\end{array}$ & $\begin{array}{c}\text { Improve } \\
64.4 \%\end{array}$ & 2 \\
\hline Kazan S et al. (10), 1999 & 2 & 16.5 & $\begin{array}{c}\text { Trauma }=1 \\
\text { Idiopathic }=1\end{array}$ & 2 & $\begin{array}{c}\text { Ressection }=1 \\
\text { Fenestration }=1\end{array}$ & $\begin{array}{c}\text { Improve } \\
100 \%\end{array}$ & 1 \\
\hline Chen HJ and Chen L (12), 1996 & 1 & 18 & Traumatic & 3 & Fenestration & $\begin{array}{c}\text { Improve } \\
100 \%\end{array}$ & N/A \\
\hline Shimizu H et al. (27), 1997 & 4 & 35 & Idiopathic & 4.5 & Ressection & $\begin{array}{c}\text { Improve } \\
100 \%\end{array}$ & 1.8 \\
\hline Paramore GG (19), 2000 & 2 & 49.5 & Idiopathic & 5 & Ressection $=2$ & $\begin{array}{c}\text { Improve } \\
100 \%\end{array}$ & N/A \\
\hline Tumialán et al. (8) 2005 & 1 & 53 & SAH & 2 & Fenestration & $\begin{array}{c}\text { Improve } \\
100 \%\end{array}$ & 0.7 \\
\hline Sharma et al. (29), 2005 & 1 & 4 & Idiopathic & 6 & Ressection & $\begin{array}{c}\text { Improve } \\
100 \%\end{array}$ & 1.5 \\
\hline Endo T et al. (30), 2010 & 6 & 38.7 & $\begin{array}{c}\text { Idiopathic }=4 \\
\text { Infection }=1 \\
\text { Traumatic }=1\end{array}$ & 7.6 & $\begin{array}{l}\text { Endoscopy } \\
\text { Fenestration }\end{array}$ & $\begin{array}{c}\text { Improve } \\
100 \%\end{array}$ & 9.5 \\
\hline Present series 2011 & 7 & 30.2 & $\begin{array}{l}\text { Idiopathic }=5 \\
\text { Traumatic }=2\end{array}$ & 4.4 & $\begin{array}{c}\text { Ressection }=5 \\
\text { Fenestration }=2\end{array}$ & $\begin{array}{c}\text { Improve } \\
85,7 \%\end{array}$ & 5.7 \\
\hline
\end{tabular}

Osenbach et al..$^{21}$ experienced deterioration of symptoms within 1 year after surgery, without evidence of cyst recurrence on follow-up MRI. It may be attributable to progressive myelomalacia secondary to vascular compromise and chronic ischemia of the spinal cord. Recently, Endo et al. ${ }^{30}$ proposed the use of endoscopy to treat the $\mathrm{AC}$ as a less invasive surgical exposure.

This current experience of 8 individuals with AC with total surgical excision or a wide fenestration of the walls of the AC and microlysis of adhesions of spinal cord proved a safe surgery without mortality and effective procedure with symptomatic improving of $57.1 \%$, result similar to others published series in the literature

\section{Conclusion}

We can assert that intradural AC is rare lesions. The majority of patients with a symptomatic intradural spinal AC have signs and symptoms of a myelopathic syndrome. AC should be considered in the differential diagnosis of lesions causing myelopathy and/or a radicular pain syndrome. Preoperative diagnostic workup of these lesions and postoperative follow-up is best accomplished by MRI. Microsurgical resection or generous fenestration in cysts effectively ameliorated patients' symptomatology.

\section{References}

1. Mohit AA, Eskridge J, Ellenbogen R, Shaffrey Cl. Aneurysmal bone cyst of the atlas: successful treatment through selective arterial embolization: case report. Neurosurgery. 2004;55(4):982.

2. Marshman LA, Benjamin JC, David KM, King A, Chawda SJ. "Disc cysts" and "posterior longitudinal ligament ganglion cysts": synonymous entities? Report of three cases and literature review. Neurosurgery. 2005;57(4):E818.

3. Freidberg SR, Fellows T, Thomas CB, Mancall AC. Experience with symptomatic spinal epidural cysts. Neurosurgery. 1994;34(6):989-93.

4. Heary RF, Stellar S, Fobben ES. Preoperative diagnosis of an extradural cyst arising from a spinal facet joint: case report. Neurosurgery. 1992;30(3):415-8.

5. Mohanty A, Venkatrama SK, Das S, Das BS, Rao BR, Vasudev MK. Spinal intramedullary cysticercosis. Neurosurgery. 1997;40(1):82-7.

6. Paolini S, Ciappetta P, Domenicucci M, Guiducci A. Intramedullary neurenteric cyst with a false mural nodule: case report. Neurosurgery. 2003;52(1):243-5.

7. Tekkök IH, Palaoglu S, Erbengi A, Onol B. Intramedullary epidermoid cyst of the cervical spinal cord associated with an extraspinal neuroenteric cyst: case report. Neurosurgery. 1992;31(1):121-5.

8. Tumialán LM, Cawley CM, Barrow DL. Arachnoid cyst with associated arachnoiditis developing after subarachnoid hemorrhage. Case report. J Neurosurg. 2005;103(6):1088-91.

9. McCrum C, Williams B. Spinal extradural arachnoid pouches. Report of two cases. J Neurosurg. 1982;57(6): 849-52.

10. Kazan S, Ozdemir O, Akyüz M, Tuncer R. Spinal intradural arachnoid cysts located anterior to the cervical spinal 
cord. Report of two cases and review of the literature. J Neurosurg. 1999;91(Suppl 2):211-5.

11. Caruso G, Germano A, Caffo M, Belvedere M, La Rosa G, De Divitiis $O$, et al. Anterior thoracic intradural arachnoid cysts. Case report and review of the literature. Neurosurg Focus. 1999;6(5):e8.

12. Chen HJ, Chen L. Traumatic interdural arachnoid cyst in the upper cervical spine. Case report. J Neurosurg. 1996;85(2):351-3.

13. Liu JK, Cole CD, Kan P, Schmidt MH. Spinal extradural arachnoid cysts: clinical, radiological, and surgical features. Neurosurg Focus. 2007;22(2):E6.

14. Liu JK, Cole CD, Sherr GT, Kestle JR, Walker ML. Noncommunicating spinal extradural arachnoid cyst causing spinal cord compression in a child. J Neurosurg. 2005;103(Suppl 3):266-9.

15. Done SL, Hayman LA, New PF, Davis KR, Chapman PH. Interdural cyst of the lumbosacral region. Neurosurgery. 1984;14(3):287-94.

16. Myles LM, Gupta N, Armstrong D, Rutka JT. Multiple extradural arachnoid cysts as a cause of spinal cord compression in a child. Case report. J Neurosurg. 1999;91(Suppl 1):116-20.

17. Nabors MW, Pait TG, Byrd EB, Karim NO, Davis DO, Kobrine $\mathrm{Al}$, et al. Updated assessment and current classification of spinal meningeal cysts. J Neurosurg. 1988;68(3):366-77.

18. Palmer JJ. Spinal arachnoid cysts. Report of six cases. J Neurosurg. 1974;41(6):728-35.

19. Paramore CG. Dorsal arachnoid web with spinal cord compression: variant of an arachnoid cyst? Report of two cases. J Neurosurg. 2000;93(Suppl 2):287-90.

20. Perret G, Green D, Keller J. Diagnosis and treatment of intradural arachnoid cysts of the thoracic spine. Radiology. 1962;79:425-9.

21. Osenbach RK, Godersky JC, Traynelis VC, Schelper RD. Intradural extramedullary cysts of the spinal canal: clinical presentation, radiographic diagnosis, and surgical management. Neurosurgery. 1992;30(1):35-42.
22. Fortuna A, La Torre E, Ciappetta P. Arachnoid diverticula: a unitary approach to spinal cysts communicating with the subarachnoid space. Acta Neurochir (Wien). 1977;39(34):259-68.

23. Sato K, Nagata K, Sugita $Y$. Spinal extradural meningeal cyst: correct radiological and histopathological diagnosis. Neurosurg Focus. 2002;13(4):ecp1.

24. Spiegelmann R, Rappaport ZH, Sahar A. Spinal arachnoid cyst with unusual presentation. Case report. J Neurosurg. 1984;60(3):613-6.

25. Alvisi C, Cerisoli M, Giulioni M, Guerra L. Long-term results of surgically treated congenital intradural spinal arachnoid cysts. J Neurosurg. 1987;67(3):333-5.

26. Teng P, Rudner N. Multiple arachnoid diverticula. Arch Neurol. 1960;2:348-56.

27. Shimizu H, Tominaga T, Takahashi A, Yoshimoto T. Cine magnetic resonance imaging of spinal intradural arachnoid cysts. Neurosurgery. 1997;41(1):95-100.

28. Nejat F, Cigarchi SZ, Kazmi SS. Posterior spinal cord herniation into an extradural thoracic arachnoid cyst: surgical treatment. Case report and review of the literature. J Neurosurg. 2006;104(Suppl 3):210-1.

29. Sharma A, Karande S, Sayal P, Ranadive N, Dwivedi N. Spinal intramedullary arachnoid cyst in a 4-year-old girl: a rare cause of treatable acute quadriparesis: case report. $J$ Neurosurg. 2005;102(Suppl 4):403-6.

30. Endo T, Takahashi T, Jokura H, Tominaga T. Surgical treatment of spinal intradural arachnoid cysts using endoscopy. J Neurosurg Spine. 2010;12(6):641-6.

\section{Correspondence address}

José Carlos Lynch

Rua Jardim Botânico, 600/605

22461-000 - Rio de Janeiro, RJ, Brazil

Telefone: (021) 2294-1937

E-mail: cneuroamericas@uol.com.br 